\title{
On Relationship of Talent Demand and Profession Construction
}

\author{
Zhiwei Cai \\ College of Naval Architecture and Ocean Engineering, Wuhan Institute of Shipbuilding Technology, \\ Wuhan, 430050, China
}

Keywords: Talent demand, Profession construction, Relationship.

\begin{abstract}
With the continuous progress of the current age, higher vocational colleges have become an important place for talent training. Colleges and universities, as the major source of talent training, must maintain the consistency between profession construction and talent demand. Therefore, study on relationship between talent demand and profession construction has a very important value for training higher education talents. This paper analyzes the relationship between talent demand and profession construction, discusses regulation of this relationship based on market economy system and puts forward some countermeasures to promote coordinated development of the relationship between talent demand and profession construction.
\end{abstract}

\section{Introduction}

Based on the study on the relationship between profession development of colleges and universities and social talent demand, it can be found that profession development of higher vocational colleges is often closely related to talent demand. Profession construction often changes with the emergence of new talent demand, and of course, characteristics of the relationship between talent demand of employers and profession construction of higher vocational colleges in the same period are not entirely consistent. However, the development of profession construction in higher vocational colleges requires guidance of the actual talent demand, but higher vocational colleges should not merely meet the needs of employers in a utilitarian way, but use career suprematism to adjust specific profession construction, which is because colleges and universities still bear the important responsibility for disseminating scientific and cultural knowledge, and developing scientific research. In view of this, profession construction of higher vocational colleges should more scientifically handle the orientation of talent demand, reasonably straighten the mutual relationship between discipline construction and profession construction, and properly adjust profession construction implementation programs, in order to better adapt to the needs of current socio-economic development and building well-off society.

\section{Relationship between Talent Demand and Profession Construction}

The first one is unified relationship. Professions in higher vocational colleges are designed based on rational division of labor and the actual needs of industrial structure by colleges, and they are an important carrier for higher vocational education talents to implement professional training. One of important aims to conduct profession construction in colleges is, in accordance with the requirements of social occupation, to use discipline advantages to develop high-quality professional talents the society needs. An important basis for the implementation of profession construction is the latest requirement for talents proposed by the current industrial structure adjustment, which is, to determine profession setting and enrollment size based on the actual employment situation of graduates, with the purpose to make graduates employed as possible. Therefore, current college students should have 
good overall quality, and generous knowledge, but also sophisticated and professional skills, which requires sustained efforts to increase professional education.

The second is opposite relationship. This is mainly embodied by that talent demand changes over time and profession construction requires stability. Profession construction needs to meet the requirements of actual jobs for professional knowledge and skills, but also meet the requirements of knowledge transfer and research development, and both must have considerable tension. Profession setting in colleges and universities must effectively balance the relationship between these two, and continue to make proper adjustment. In terms of the current reality of profession setting in higher vocational colleges, there exists significant inconsistencies between profession construction and talent demand. Specifically, profession setting in higher vocational colleges still lags behind economic development, for example, the authority for profession configuration, courses adjustment and enrollment size is concentrated in education departments, however, colleges and universities lack corresponding right to choose and adjust, and once any problem appears in the teaching process, it requires to be reported to several levels, then to be effectively addressed through the application of administrative measures by the country after considering comprehensively. At the same time, the conflict exists between the stability of profession design in higher vocational colleges and the volatility of employment in the socialist market economy with Chinese characteristics. Entities related to profession setting, such as curriculum arrangement, teacher allocation, teaching funds, and teaching facilities, are important factors in profession construction adjustment. So, either external pressure or internal inertia, contributes to strong sense of stability of profession construction. As a result, what students learn is relatively fixed. However, with the rapid development of modern science and technology, the demand for talent is provided with irregular fluctuations. Moreover, effectiveness of profession construction can be reflected only until subject to the test after graduation employment.

The third is dependent relationship. Demand of socio-economic development for talents provides development power for profession construction of higher vocational education, and profession construction of higher vocational education promotes the improvement of the talent quality, which in turn promotes the development of national economic construction. This is both interdependent and mutually reinforcing relationship. Higher vocational colleges should conform to the needs of economic development, actively develop profession construction, enhance the capacity of professional services industry of higher vocational colleges, and focus on building professional skills training center, production technology testing center, science and technology laboratory, to make higher vocational colleges become technical pillar and backing of local economic development, and training and testing center become a combined entity of "production, learning and research". Local enterprises take the initiative to do experiments and feasibility studies on advanced technology and production processes in higher vocational colleges, and higher vocational colleges should also initiatively find research direction, research subjects and projects in local enterprises, to service local businesses, and support regional economic development. In this mutually supportive and interdependent relationship, higher vocational colleges can achieve self-construction and development.

\section{Discussion on adjusting relationship between talent demand and profession construction based on market economy system}

Since the establishment of market economy in our country, our economic system has new changes. Market economy and traditional planned economy are different essentially in nature, which is both opportunity and challenge for Chinese colleges and universities, leading to the fundamental change of talent demand, which requires reasonable reform of profession construction. Specific to the higher vocational education personnel training, after freed from the planned economy, talent training changed towards the direction of quality education. Courses setting gradually realizes integration, diversification and internationalization of curriculum content; practice base creation begins to pay more attention to construction of practice-oriented bases, increasing investment in human, material 
and financial resources, and implementing more standardized management; teacher's personnel development puts more emphasis on the improvement of overall quality and education level of teachers, so as to train new talents able to adapt to the current social needs.

Under the background of market economy, the effect of actual talent demand on profession construction becomes more and more profound and direct. Profession construction in higher vocational colleges can flexibly and initiatively adapt to changing demand for talents. Higher vocational colleges begin trying to be more proactive to adapt to social practical needs, and higher vocational colleges under the government control and intervention also appear weakened gradually. This is because higher vocational colleges in market economy are also independent economic entities, bound to have supply and demand relationship with the market, and the government only plays a role of guidance and supervision. That is to say, the higher education operation system based on the market economy is the relationship between the government, colleges and market. To explore the relationship between colleges and market, their social value must be determined by the market because they are also independent entities, therefore, it can be said that the market is the most important driving force for higher vocational colleges to achieve new development. As for the relationship between the market and the government, it can be found that talent demand in the market economy system has increasingly direct effect on professional personnel in higher vocational colleges and the ability of higher vocational colleges to adapt to the actual talent demand is increasingly improved. This is because after the arrival of the era of knowledge economy, knowledge updating speeds up constantly, and talent demand shifts towards the complex type, which requires colleges and universities to effectively change the traditional concept of professional matching, and re-establish the new talent concept based on quality and capacity, thereby forming a new training model integrating scientific and technological knowledge and ability improvement. Meanwhile, the government should return the authority to set up profession to colleges and universities, and allow higher vocational colleges to make professional adjustment based on the current actual demand for talents and resources conditions.

\section{Some Countermeasures to Promote Coordinated Development of the Relationship between Talent Demand and Profession Construction}

\section{Comply with actual economic development and reasonably adjust profession setting in higher vocational colleges}

Now, China is facing new opportunities for industrial transformation and development. Strengthen the research on economy development situation and the employment market, and effectively develop countermeasures able to promote new development of local economic society, in order to achieve the role transformation from manufacturing country to innovation country. Actively undertake a new round of international industrial transfer boom, devote to the development of service outsourcing, financing, creation and other emerging industries. Increase development efforts of logistics, information and other service industries, to better promote the development of related industries, and use unconventional way to enhance the size and level of economic development. Higher vocational colleges should actively adapt to the actual situation of the local economic transition and the demand for talents, rapidly adjust and improve various profession setting, and in particular, well set up professions closely related to the current economic hot topics. Despite of stable requirements profession setting in higher vocational colleges, but due to economic and social sustainable development and change, actual positions will also require reasonable adjustment. Therefore, profession setting in higher vocational colleges also needs reasonable adjustment. Indeed, the process of running the school by higher vocational colleges is the important requirement to continuously promote local economic and social development, and implement continuous adjustment and optimization of profession setting. This requires our higher vocational colleges to focus on the new change in the talent market, and reasonably improve the profession setting, so as to train lots of highly skilled professionals for enhancing the level of local economic and social development. 


\section{Improve profession setting methods and train comprehensive talents}

Currently, various higher vocational colleges vigorously readjust the traditional methods of profession setting, committed to train new talents with good overall quality. Specifically, talent training methods based on profession setting include as follows. First, set up large professions. Merger similar professions or set up interdisciplinary and comprehensive professions. Second, set up professions later. Enroll students according to large disciplines and then set up specific expressions, which is the main feature of this method. And this mode can be mainly used for overall knowledge plus professional education, basic plus professional education, generalist plus specialists education and other forms. This mode can better break through professional limitations than the former one, so as to nurture high-quality and comprehensive talents, which should be learned by higher vocational colleges. Third, avoid fixed profession setting. This can comprehensively avoid cracking various types of knowledge due to professional division, committed to train comprehensive talents. For example, Sun Yat-sen University founded the liberal arts college, which implements elite education model regardless of specific professions for undergraduates. The aim to implement interdisciplinary elite education model is to use general education to develop education elites without professions. Today, this method has become the ideal way for comprehensive talent training, and its effectiveness remains to be concluded, but it has become an important reference for the future reform of higher education, and many higher vocational colleges also wait and see.

\section{Implement profession construction based on courses construction}

It can be said that courses construction is an important part of profession construction in higher vocational colleges, which can integrate talent training goal of higher vocational colleges into specific teaching content and teaching process, so that it can play directional and normative role in specialized personnel training in fact. A number of interrelated courses can be combined into a complete curriculum system, and all professional courses content can be divided into a number of different levels, including basic quality and ability courses, professional quality and ability courses, quality education and ability expansion, career guidance and innovation and entrepreneurship courses. China's current curriculum model in higher vocational colleges is from professional teaching to courses learning, and then to job market, so that the employment will be placed in the final part of talent training, resulting in that it is very difficult to adapt to the requirements of modern market for talent training. To further enhance talents' ability to adapt, higher vocational colleges must at the most extent form the talent training mode able to proactively adapt to the development needs of modern society, from employment to courses learning, then to implementation of professional education. This is because higher vocational education talent training is cyclical and long-term, and professions and subjects should not change just according to the market demand, which is also an important issue difficult to be avoided in profession construction in higher vocational colleges. But, relatively speaking, courses are likely to be changed, and in fact advantage of professional education is often embodied by the use of courses education. Therefore, courses construction naturally becomes the most important part of profession construction, but also the basis to enhance the quality of professional education. Development of foreign higher vocational colleges tend to be based on curriculum adjustment according to the latest science and technology, industry trends, not simply changing the profession name, which is worthwhile to be learned by higher vocational colleges in China.

\section{Conclusions}

In summary, there is unified, also conflicting and even interdependent relationship between social talent demand and profession construction in colleges and universities. It is difficult to achieve long-term balance between profession construction and talent demand. To achieve coordinated development between these two, we should effectively reform the existing profession construction methods in colleges and universities, take courses construction as the base, and conduct reform step 
by step. Meanwhile, in terms of profession construction, conform to actual demand of employer for talents, and comprehensively adjust curriculum system after a comprehensive analysis on talent demand, so as to better adapt to talent training goals of higher vocational colleges and functions of serving the society.

\section{References}

[1] Cao Hongjun. Rational Reflection on Establishing College Profession Setting Forecasting System. Liaoning Education Research, 2008 (3).

[2] Xiao Janle, Sun Dehua. Thoughts on Chinese Higher Education Talent Training Model. Fujian Forume, 2009 (10).

[3] Xu Shihao. Strategy Research on Convergence of Profession Construction and Regional Economic Development under Economic Restructuring Background. Education, 2010

[4] Cai Liang. On Structural Imbalance of Graduate Employment Market and Profession Setting. Employment and Entrepreneurship,2010 (11). 